Recorregut circular de recerca geològica i mineralògica per la comarca del Ripollès: des de Sant Joan de les Abadesses a les Mines de Perella, Sant Pau Seguries, Colònia Estevenell, Surroca, Ogassa i a Sant Joan de les Abadesses

Josep Maria Mata-Perelló

Joaquim Sanz Balagué

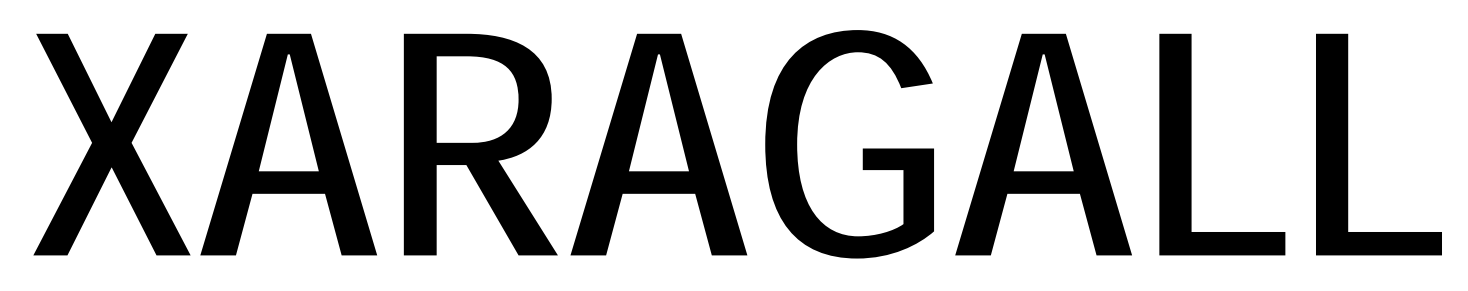

REVISTA DE CIÈNCIES DE LA CATALUNYA CENTRAL n. 7

JULIOL 2014 


\section{RECORREGUT CIRCULAR DE RECERCA GEOLÒGICA I MINERALÒGICA PER LA COMARCA DEL RIPOLLÈS: DES DE SANT JOAN DE LES ABADESSES A LES MINES DE PERELLA, SANT PAU SEGURIES, COLÒNIA ESTEVENELL, SURROCA, OGASSA I A SANT JOAN DE LES ABADESSES}

\section{Josep Maria Mata-Perelló}

Museu de geologia Valentí Masachs, Escola Politècnica Superior d'Enginyeria de Manresa (EPSEM), Universitat Politècnica de Catalunya · BarcelonaTech (UPC), 08272 Manresa, Spain

\section{Joaquim Sanz Balagué}

Departament d'Enginyeria Minera i Recursos Naturals (EMRN), Escola Politècnica Superior d'Enginyeria de Manresa (EPSEM), Universitat Politècnica de Catalunya - BarcelonaTech (UPC), 08272 Manresa, Spain

Paraules clau: Sistema Pirinenc; Zona Sudpirenenca; Geologia; Mineralogia

\section{Resum}

Itinerari realitzat el 22 de juny de 2013. El recorregut del present itinerari, es desenvoluparà íntegrament pel Sistema Pirinenc; i més concretament: per la zona de contacte entre la Zona Sudpirenenca i la Zona Axial del Sistema Pirinenc. Així, s'iniciarà dintre de la Zona Sudpirenenca, prop de la població de Sant Joan de les Abadesses, des d'on s'anirà cap Ant Pau de Seguries. Poc després d'aquesta població, entrarem al Mantell del Cadí, que ja no abandonarem fins arribar prop de Sant Joan de les Abadesses, ja en el recorregut de tornada.

Tot i això, en diferent trams del recorregut entre la Colònia ESTEVENELL i Sant Martí de Surroca, passarem prop de I'Encavalcament de Ribes de Fresser - Setcases, al Sud del Mantell del Canigó.

Per d'altra banda, també cal dir que aquest recorregut s'efectuarà, íntegrament per la comarca pirinenca del Ripollès.

Xaragall.2014 n.7 | Recorregut circular de recerca geològica i mineralògica per la comarca del Ripollès: des de Sant Joan de les Abadesses a les Mines de Perella, Sant Pau Seguries, Colònia Estevenell, Surroca, 


\section{Objectius fonamentals}

A través d'aquest itinerari geològic-mineralògic, s'intentaran d'aconseguir els següents objectius:

1. Observació i estudi del materials cenozoics (fonamentalment de l'Eocè), que formen part del Mantell del Cadí. Aquests materials es distribueixen entre les següents formacions: Formació del Cadí, Formació Sagnari, Formació Banyoles, Formació Corones, Formació Vallfogona, Formació Campdevànol, Formació Armàncies i Formació Bellmunt. Fonamentalment, les tallarem inicialment entre Sant Joan de les Abadesses, les Mines de Perella, Sant Pau de Seguries i la Colònia ESTEVENELL, fonamentalment. També els tallarem a la fi del recorregut, entre Ogassa i Sant Joan de les Abadesses.

2. Observació i estudi del materials mesozoics (exclusivament del Cretàcic, i més concretament del Garumnià), que formen part del Mantell del Cadí. Aquests materials, de molt escassa potència en diferents indrets del recorregut, com pels voltants de la Colònia ESTEVENELL; i també prop de Surroca i d’Ogassa, entre altres indrets del recorregut.

3. Observació i estudi dels materials paleozoics (del Silurià, Devonià, Carbonífer i Pèrmic), que formen part dels relleus del Mantell del Cadí., i que tallarem per diferents indrets del recorregut; especialment entre la Colònia ESTEVENELL, Ogassa i Surroca.

4. Observació a distancia dels materials paleozoics (del Silurià, Ordovicià Devonià i del Carbonífer), que formen part dels relleus de la Zona Axial Pirinenca. Aquests materials no els tallarem en el recorregut; tot i que circularem prop, pels voltants de Surroca i d'Ogassa. Així, anirem al Sud de l’Encavalcament de Ribes de Fresser - Setcases - Camprodon o Falla de Camprodon-Ribes de Freser

5. Visió de les relacions, i dels contactes existents entre les dues sots-unitats pirinenques abans esmentades.

6. Estudi de diverses mineralitzacions situades al llarg del recorregut de l'itinerari, com les mineralitzacions ferruginoses associades a pirites incloses en carbons, que trobarem pels voltants de Surroca, entre altres llocs, ubicades entre els afloraments paleozoics del Carbonífer

7. Estudi i observació de les explotacions relacionades amb els afloraments de les mineralitzacions acabades d'esmentar.

8. Estudi i observació de les alteracions del Medi Natural produïdes a partir de les explotacions anterior. I si s'escau de les restauracions ambientals dutes a terme per tal $\mathrm{d}^{\prime}$ aminorar aquests impactes.

9. Observació dels afloraments de falgueres fòssils, localitzades entre els materials Carbonífers de Surroca.

10. Observació al llarg del recorregut, dels diferents indrets relacionats amb el Patrimoni Geològic i Miner. Dintre d'aquest darrer, cal considerar tot el relacionat amb les antigues explotacions mineres de la Conca Carbonosa de Sant Joan de les Abadesses (o millor dit de Surroca - Ogassa).

Xaragall.2014 n.7 | Recorregut circular de recerca geològica i mineralògica per la comarca del Ripollès: des de Sant Joan de les Abadesses a les Mines de Perella, Sant Pau Seguries, Colònia Estevenell, Surroca, 


\section{Antecedents}

Sense indexació i Hi ha alguns antecedents, relatius a itineraris geològics i mineralògics, el quals discorren per indrets propers al present. Entre aquests, farem esment de diversos treballs nostres, com els següents: Mata-Perelló (1995, 1996a, 1996b, 1996c, 1997a, 1997b, 1998, 2007, 2011a i 2011b). També farem esment de dos treballs més, on hi ha itineraris coincidents parcialment amb el present. Es tracta de: Mata-Perelló i Font Soldevila (1995), i de MataPerelló i Sanz Balagué (1991).

Pel que fa a les mineralitzacions que veurem en aquest itinerari, cal dir que ja estat prèviament descrites per nosaltres en un altre treball (d'àmbit general referit al conjunt de Catalunya), al qual ens remetin. Es tracta de Mata-Perelló (1991).

Per d'altra banda, en canvi, farem esment de diversos treballs, de caràcter geològic general i regional, com són els següents: Guimerà et altri (1992), i Riba et altri (1976). Tanmateix, i pel que fa a les monografies regionals, farem esment dels treballs: IGME (1991 i 1994).

Tots aquests treballs, figuren convenientment referenciats, per estricte ordre alfabètic, dintre de I'apartat dedicat a les REFERÈNCIES BIBLIOGRÀFIQUES, al qual ens remetin.

\section{Recorregut de l'itinerari}

El recorregut de l'itinerari, s'iniciarà a la població de Sant Joan de les Abadesses, des d'on s'anirà, cap a les immediacions de Sant Pau de Seguries, amb la intenció de realitzar una parada a les Mines de Perella. Després. El recorregut es dirigirà cap a la població de Sant Pau de Seguries, des d'on s'anirà cap a la Colònia ESTEVENELL. En aquest tram, s'efectuaran diverses aturades.

Tot seguit, el recorregut es dirigirà per una pista enformigonada, cap a Surroca i Ogassa, des d'on es retornarà a Sant Joan de les Abadesses, per on finalitzarà el recorregut d'aquest itinerari, després de efectuar diverses aturades.

\section{Advertiments previs}

Com en altres recorreguts de RECERCA GEOLÒGICA I MINERALÒGICA ..., si es disposa del temps suficient, poden efectuar-se passant per totes les parades i filloles. En cas contrari, recomanem prescindir de les anomenades PARADES - CONDICIONALS.

Cal dir també, que en aquest itinerari ens trobarem diferents de trams de camins forestals en molt mal estat de conservació; per la qual cosa serà molt millor transitar a peu per ells, com és el cas de l'accés a les Mines de Perella.

I, finalment, en qualsevol cas, cal tenir sempre una cura molt especial de respecte a la natura, al llarg de tot el recorregut; de l' itinerari.

Xaragall.2014 n.7 | Recorregut circular de recerca geològica i mineralògica per la comarca del Ripollès: des de Sant Joan de les Abadesses a les Mines de Perella, Sant Pau Seguries, Colònia Estevenell, Surroca, 


\section{Descripció de l'itinerari}

Com de costum, estructurarem el recorregut de l'itinerari en una sèrie de PARADES (o d'ESTACIONS), que tot seguit anirem veient. En cadascuna d'aquestes aturades farem un breu comentari (geològic o mineralògic, segons s'escaigui).

Per d'altra banda, en cada cas indicarem, entre parèntesi, el full topogràfic on es troba I'aturada. Finalment, cal dir que el recorregut de l'itinerari s'inclourà dintre dels següents dos fulls: 255 (dit de la Pobla de Lillet) i 256 (o de Ripoll). Aquests fulls estan editats per IGC de España, a una escala de 1:50.000.

Així doncs, la relació general de les parades que constitueixen el recorregut d'aquest itinerari, és la següent:

\subsection{Parada 1. LA GUIXERA, (terme municipal de Sant Joan de les Abadesses, comarca del Ripollès). (Full 256).}

El recorregut I'haurem iniciat al bell mig de Sant Joan de les Abadesses. Tot seguit, cal agafar la carretera $\mathrm{N}-260$, en sentit oriental. A poca distància del poble, cal seguir per un camí que es dirigeix cap al Sud, i que condueix cap al paratge de la guixera. En aquest indret, situat a uns $3 \mathrm{Km}$ de la població, és on ens cal fer la present aturada.

En aquest recorregut, s'aniran tallant els materials cenozoics que formen part dels relleus pirinencs del Mantell del Cadí. Fonamentalment es tracta de trams de calcolutites grisenques, trams de turbidites també grisenques. Tots aquests materials son els que es troben pels voltants de Sant Joan de les Abadesses.

Aquests materials són també els que apareixen a l'indret de l'aturada, on afloren uns nivells de guixos, els quals pertanyen a la Formació Campdevànol. En efecte, aquí hi ha un aflorament dels nivells de guixos, els quals pertanyen a la. Aquests han estat explotats, per tal de dedicarlos a una antiga guixera. (fotografia 1.)

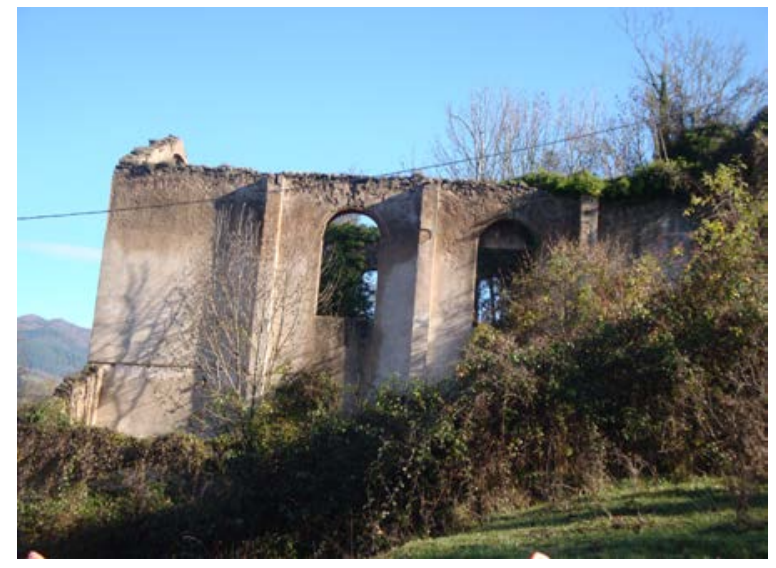

Fotografia 1. Un aspecte de l'antiga guixera

Per d'altra banda, al costat de la guixera anterior, n'havia una altra molt més antiga, un interessant Forn de Guix (fotografia 2). Aquest, forma part del Patrimoni Miner de la comarca de la Garrotxa.

Xaragall.2014 n.7 | Recorregut circular de recerca geològica i mineralògica per la comarca del Ripollès: des de Sant Joan de les Abadesses a les Mines de Perella, Sant Pau Seguries, Colònia Estevenell, Surroca, 


\subsection{Parada 2. ANTIGUES MINES DE PETROLI DE SANTA MARIA DE PERELLA, (terme municipal de Sant Joan de les Abadesses, comarca del Ripollès). (Full 256).}

Després de fer l'aturada anterior, cal retornar a la carretera C- 26 / N - 260. En arribar a la cruïlla de la carretera a Olot, ens caldrà seguir cap a Sant Pau de Seguries. Poc després de la cruilla trobarem el camí de Santa Maria de Parella. Després, des del primer revolt haurem de seguir a peu. En arribar a les mines farem una nova aturada, a uns $4 \mathrm{Km}$ de l'anterior.

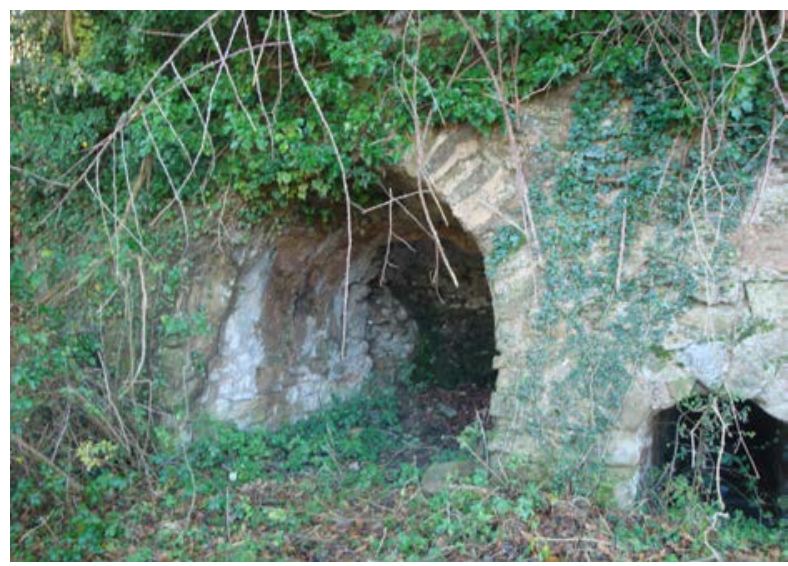

Fotografia 2. Un aspecte del Forn de Guix

En aquest recorregut, hem continuat trobant els materials esmentats anteriorment. els quals formen part de les següents unitats litoestratigráfiques: Formació Vallfogona (amb nivells de calcolutites i de gresos, i que la presenten intercalacions del nivells de guixos de la Formació Campdevànol), Formació Armàncies (amb calcolutites noduloses gris-blavoses). En aquests indrets hi va aparèixer petroli entre els materials acabats d'esmentar. Aquest petroli va ser objecte d'intents fracassats d'explotació. (fotografia 3).

En torn a la les bocamines encara es conserven diferents edificis, tot i que en un precari estat de conservació. (fotografia 4).

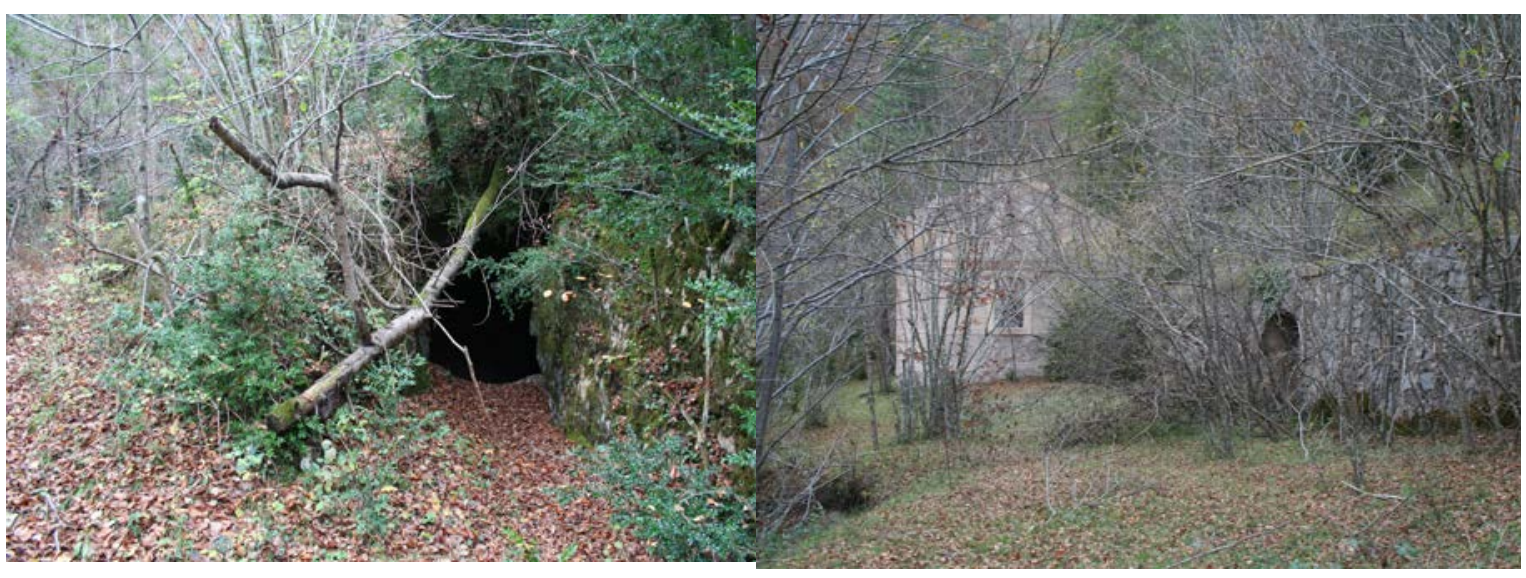

Fotografia 3. Una de les bocamines

Fotografia 4. Restes dels edificis miners

Xaragall.2014 n.7 | Recorregut circular de recerca geològica i mineralògica per la comarca del Ripollès: des de Sant Joan de les Abadesses a les Mines de Perella, Sant Pau Seguries, Colònia Estevenell, Surroca, Ogassa i a Sant Joan de les Abadesses. 


\subsection{Parada 3. INICI DEL CAMÍ A SURROCA I A OGASSA, DES DE LA COLÒNIA ESTEVENELL, (Colònia Estevenell, terme municipal de Camprodon, comarca del Ripollès). (Full 256).}

Després de fer l'aturada anterior, cal retornar a la carretera C- 26 / N - 260. En arribar- hi, ens cal continuar cap a Sant Pau Seguries, continuant per la carretera autonòmica C - 38. Així, arribarem a la Colònia Estevenell. Des d'aquí, ens convindrà agafar el camí enformigonada que es dirigeix cap a Surroca i Ogassa. Quasi a l'inici del camí, podem fer una nova aturada, a uns $6 \mathrm{Km}$ de la parada anterior i a uns 3 de Sant Pau de Segúries.

En aquest recorregut, harem estat circulant per entre els afloraments dels materials eocènics de I'llerdià, dintre del Mantell del Cadí. Més amunt haurem trobat afloraments dels materials cretàcics del Garumnià, de caràcter carbonatat. I més amunt, haurem trobat els afloraments dels materials rogencs del Permotries, amb nivells de gresos i calcolutites de tonalitats rogenques. Aquests són els materials que apareixen a l’indret de la present aturada.

Per d'altra banda, des d'aquest indret, mirant cap al SE, podem veure un interessant aflorament dels nivells carbonatats del Garumnià, de les anomenades "calcàries de Vallcebre". (fotografia 5).

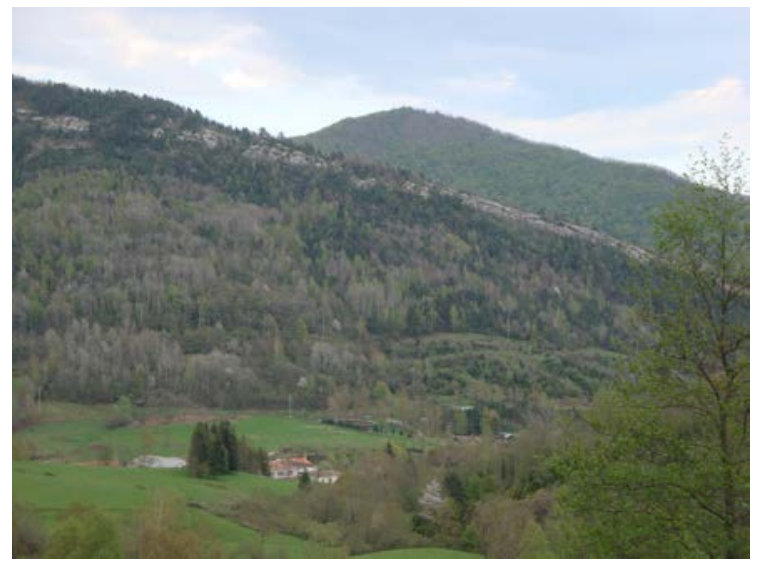

Fotografia 5. Puig de Dot. Colònia Estevenell

\subsection{Parada 4. CAMÍ A SURROCA I A OGASSA, IMMEDIACIONS DE CAN PANER, (Colònia Estevenell, terme municipal de Camprodon, comarca del Ripollès). (Full 256).}

Després de fer l'aturada anterior, cal continuar pel camí que es va dirigent cap a ponent, cap a Surroca i Ogassa. En arribar a les immediacions de Can Paner, podem fer una nova aturada, després d’agafar el camí que res dirigeix cap al Castell de CABALLERA. Així, des de la parada anterior, haurem recorregut uns $2 \mathrm{Km}$ i escaig, per tal d'arribar fins aquí.

Xaragall.2014 n.7 | Recorregut circular de recerca geològica i mineralògica per la comarca del Ripollès: des de Sant Joan de les Abadesses a les Mines de Perella, Sant Pau Seguries, Colònia Estevenell, Surroca, 
En aquest recorregut, haurem trobat afloraments dels materials que hem vist a l'aturada anterior, dels trams de tonalitats rogenques del Permià. Aquest són també els materials que apareixen a l'indret de l'aturada, situant-nos dintre del Mantell del Cadí.

Per d'altra banda, mirant cap a llevant, cap a I'altre cantó de la Colònia Estevenell, podem veure unes interessants estructures, entre les calcàries del Garumnià i els materials del Permià. Així, es fan visibles algunes fractures, situades als Costalets. (fotografia 6).

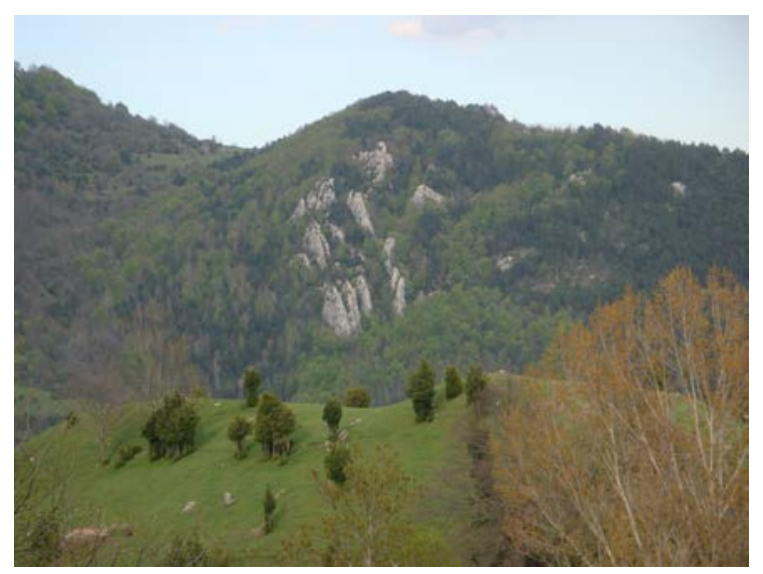

Fotografia 6. Els Costelets. Colònia Estevenell

\subsection{Parada 5. PLA D’EN PLATA, (terme municipal de Camprodon, comarca del Ripollès). (Full 256).}

Després de fer l'aturada anterior, cal continuar cap a ponent, seguint sempre el camí en bon estat (enformigonada) que es va dirigint cap a Surroca i cap a Ogassa. En arribar al Pla d'en Plata, podem fer una nova aturada, després de recórrer uns $4 \mathrm{Km}$ més, des de la parada anteriorment realitzada.

La totalitat del recorregut, s'haurà efectuat entre afloraments dels materials paleozoics del Pèrmic, que són els que apareixen a l'indret de l'aturada. Així, per arreu, veurem afloraments del materials terrígens detrítics del Permià. Aquests materials també apareixen a l'indret de I'aturada. Per d'alta banda, també haurem trobat afloraments dels materials del Carbonífer, amb gresos, calcàries i calcolutites. Tots aquests materials es troben situats dintre del Mantell del Cadí.

Des d'aquest indret, mirant cap el Sud, es poden veure unes interessants estructures dels materials del Subpirineu i del Mantell del Cadí, al Sud d'o ara som. Per d'altra banda, en aquest indret es pot veure uns aiguamolls, en part artificials, amb formació de torberes i de torbes. (fotografia 7).

Xaragall.2014 n.7 | Recorregut circular de recerca geològica i mineralògica per la comarca del Ripollès: des de Sant Joan de les Abadesses a les Mines de Perella, Sant Pau Seguries, Colònia Estevenell, Surroca, 


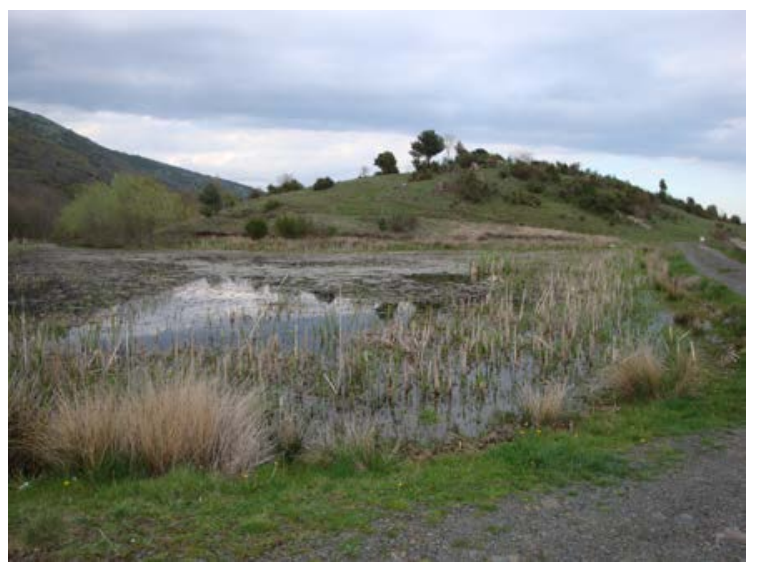

Fotografia 7. Aiguamolls del Pla d'en Plata, terme de Camprodon

\subsection{PARADA 6. IMMEDIACIONS DE FOGONELLA, (terme municipal de Surroca i Ogassa, comarca del Ripollès). (Full 256).}

Després de fer l'aturada anterior, cal continuar per la pista que es va dirigint cap a Surroca i Ogassa. Però en arribar prop de Fogonella, podem fer una nova aturada, després de recórrer poc menys de $2 \mathrm{Km}$, des de la prada anterior, anant sempre cap a ponent.

En aquest recorregut, haurem trobat afloraments esmentats a les aturades anteriors. Aquests afloraments pertanyen majoritàriament als trams detrítics i terrígens del Permià. Ocasionalment, haurem trobat afloraments dels materials pissarrencs del Carbonífer. Per d'altra banda, continuem estant sempre dintre del Mantell del Cadí.

Per d'altra banda, al Nord d'on ara som, es fa palès l'Encavalcament de Ribes de Fresser Setcases - Camprodon, trobant-se al nord d'on ara som els materials paleozoics del Carbonífer i del Devonià (predominat aquests darrers, de caràcter carbonatat), de la Serra del Pedró dels tres Batlles i de la Serra del Collsabarca

Per d'altra banda, mirant cap el SSE, veurem els relleus del Subpirineu i del Cabrerés (de la Serralada Transversal). En tots dos casos, es tracta dels afloraments dels materials cenozoics, fonamentalment de l'Eocè. (fotografia 8).

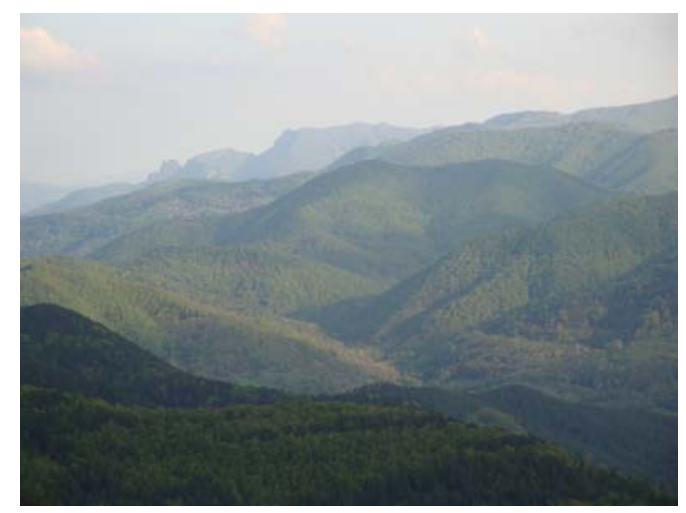

Fotografia 8. El Subpirineu i el Cabreres, des de les immediacions de Fogonella

Xaragall.2014 n.7 | Recorregut circular de recerca geològica i mineralògica per la comarca del Ripollès: des de Sant Joan de les Abadesses a les Mines de Perella, Sant Pau Seguries, Colònia Estevenell, Surroca, 


\subsection{Parada 7. COLL DE LA CREU, (terme municipal de Surroca i Ogassa, comarca del Ripollès). (Full 256).}

Després de fer l'aturada anterior, cal continuar cap a ponent pel camí que ens va apropant a Surroca i a Ogassa. En arribar al Coll de la Creu, podem fer una nova aturada, si s'escau, a poc més de $1 \mathrm{~km}$ de la parada anterior.

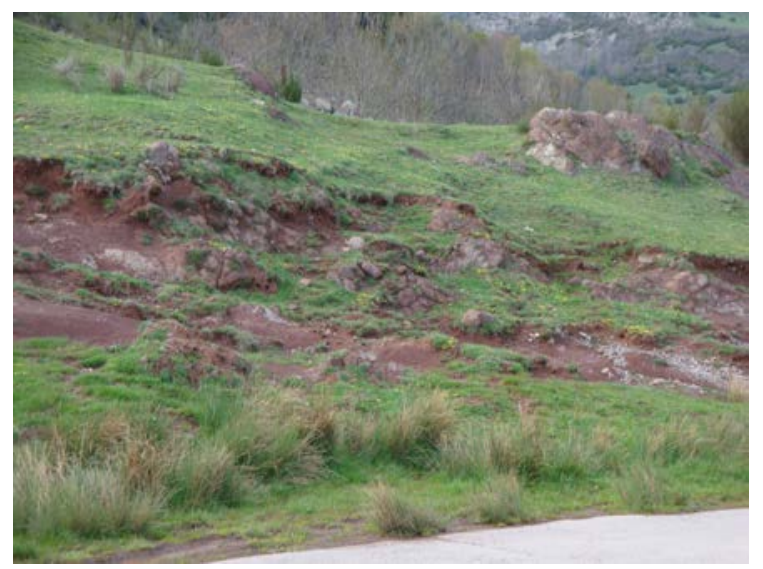

Fotografia 9. Afloraments del Permotries, en el Coll de la Creu

En aquest recorregut, hem anat circulant sempre entre afloraments dels materials paleozoics del Pèrmic. Aquests són els materials terrígens i rogencs, que apareixen a l'indret de la present aturada. (fotografia 9).

Per d'altra banda, en aquest recorregut, haurem continuat veient (mirant cap el Sud), els relleus del Subpirinueu i del Cabrerès, dels que ja hem parlat a la parada anterior. Tanmateix, mirant cap el nord veurem el relleu paleozoic del Padró dels Batlles, dl qual ja n'hem parlat a la parada anterior.

\subsection{Parada 8. IMMEDIACIONS DE SANT MARTÍ SURROCA, (terme municipal de Surroca i Ogassa, comarca del Ripollès). (Full 256).}

A continuació de fer l'aturada anterior, cal continuar per la pista, cap a Surroca i cap a Ogassa. En arribar a Sant Martí de Surroca, podem fer una nova aturada, a uns $2 \mathrm{Km}$ de la parada anterior.

En aquest recorregut, haurem continuat trobant afloraments dels materials detrítics rogencs, del Permotries. Tanmateix, haurem trobat afloraments dels nivells pissarrencs del Carbonífer. Uns i altres es situen dintre del Mantell del Cadí.

Per d'altra banda, mirant cap el Nord, es poden veure els relleus carbonatats del Padró dels tres Batlles. Es tracta d'una mola carbonatada, del Devonià, situada al Nord de I'Encavalcament de Ribes de Fresser - Setcases - Camprodon. (fotografia 10).

Xaragall.2014 n.7 | Recorregut circular de recerca geològica i mineralògica per la comarca del Ripollès: des de Sant Joan de les Abadesses a les Mines de Perella, Sant Pau Seguries, Colònia Estevenell, Surroca, 


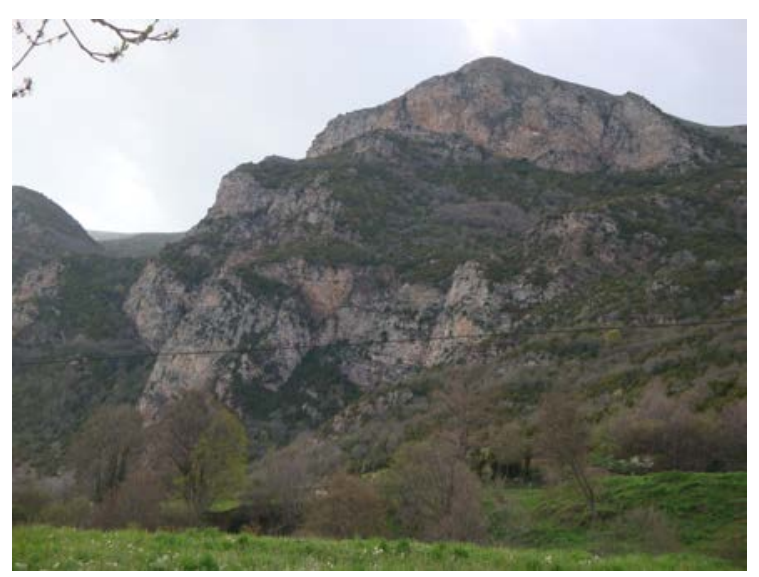

Fotografia 10. La Pedra dels Tres Bisbats

\subsection{Parada 9. MINES DE CARBÓ DE SANT MARTí DE SURROCA, (terme d’Ogassa, Comarca del Ripollès). (Full 256).}

Des de la parada anterior, cal continuar pel camí que es va dirigent cap a Ogassa, poc després de realitzar la parada anterior, podem efectuar una altra. Aquesta la farem en un revolt pronunciat, al costat de l'escombrera d'una Mina de Carbó. Així, des de la parada anterior, haurem feu un recorregut proper a $1 \mathrm{Km}$

En aquest recorregut, s'han anat tallant els materials paleozoics del Carbonífer, i també els nivells del Permià. Uns i altres formen part del Mantell del Cadí, al qual ens hem referit anteriorment.

En aquest indret, hi ha les restes d'una antiga explotació dels nivells carbonosos de la Conca de Surroca-Ogassa. Tot i així, el fet més interessant, és l'abundant presència de restes de falgueres fòssils, situades entre els nivells esquistosos del Carbonífer. Però, tot i I'abundor d'aquests fòssils vegetals, recomanem veure'ls, sense arrancar-los.

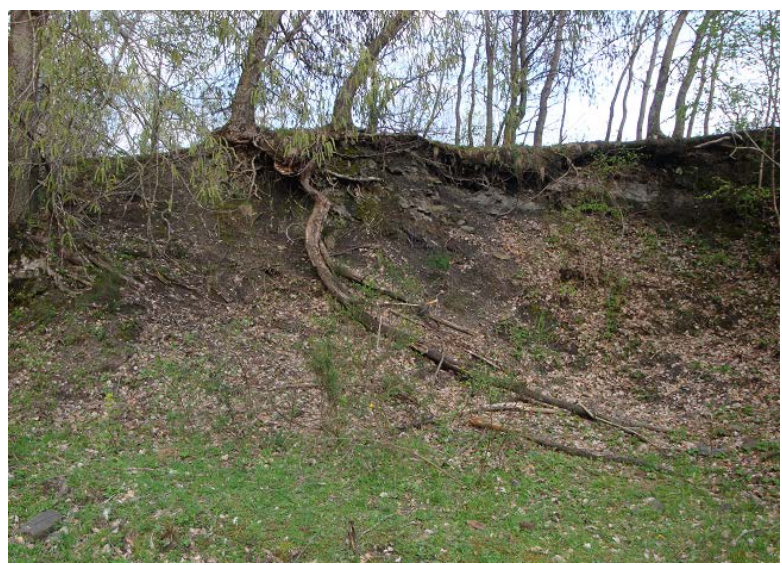

Fotografia 11. Antiga escombrera del camí de la mina de Sant Martí de Surroca

Xaragall.2014 n.7 | Recorregut circular de recerca geològica i mineralògica per la comarca del Ripollès: des de Sant Joan de les Abadesses a les Mines de Perella, Sant Pau Seguries, Colònia Estevenell, Surroca, 


\subsection{Parada 10. MINA DOLÇA, MUSEU DE LES MINES DE SURROCA - OGASSA, (Surroca de Baix, terme d'Ogassa, comarca del Ripollès). (Full 256).}

Després de fer la parada anterior, cal continuar pel camí que es dirigeix cap a les immediacions d'Ogassa, deixant enrere el trencall de Bruguera. Poc abans d'arribar I nucli principal de la població, ens caldrà fer una nova aturada Aquesta la farem a l'antiga Mina Dolça, a uns $4 \mathrm{Km}$ de la parada anterior.

En tot aquest recorregut, es van tallant primer els materials eocènics, dels quals ja n' hem parlat a la parada anterior. Així, després de trobar la Formació Armàncies (amb calcolutites noduloses gris-blavoses), trobarem la Formació Corones (amb gresos i calcàries microlítiques grisenques), Formació Sagnari (amb calcolutites grisenques) i Formació Cadí (molt poc representada, amb nivells de calcàries amb alveolines).

En aquest lloc, ens trobem en un aflorament dels nivells paleozoics del Carbonífer, els qual formen part del Mantell del Cadí, molt a prop ja de l'encavalcament de la Serra Caballera, el qual posa en contacte aquest mantell amb els Apilaments Antiformes del Freser, que es situen per sobre de l'esmentat mantell.

Aquests materials paleozoics del Carbonífer, es troben constituïts per alternances de nivells detrítics (els quals predominen a la base de la formació), amb nivells foscos i nivells d'hulles. Aquests materials constitueixen I'anomenada Unitat de Transit (IGME, 1991b), la qual pertany en realitat a I'Estefano-Permià. freqüentment, entre aquests nivells, i en especial entre els detrítics, es troben abundants intercalacions volcàniques.

Els nivells d'hulla foren explotats durant quasi un segle, en aquesta Conca de Surroca-Ogassa (o de Sant Joan de les Abadesses), aprofitant-se quatre nivells, de molt variada riquesa. Les mines es troben repartides per diferents indrets de Surroca i per Ogassa. Actualment, a la Mina Dolça, s' ha establert un interessant Museu Miner, que actualment es troba parcialment tancat, després d'esfondrament. (fotografies 12 i 13).

Per d'altra banda, cal dir que actualment, a moltes de les escombreres poden trobar-se mostres de: MARCASSITA, PIRITA, GOETHITA (limonítica i terrosa) i MELANTERITA, entre altres minerals. Tanmateix apareixen altres minerals com GUIX i CALCITA, sovint força abundants. També, gaudeixen de reconegut coneixement, les restes de falgueres fòssils que es troben entre els nivells d'hulla. Hi ha un indret, prop del poble, on hi ha forà restes d'aquests vegetals: a la bora del recorregut de l'antic ferrocarril.

Xaragall.2014 n.7 | Recorregut circular de recerca geològica i mineralògica per la comarca del Ripollès: des de Sant Joan de les Abadesses a les Mines de Perella, Sant Pau Seguries, Colònia Estevenell, Surroca, 


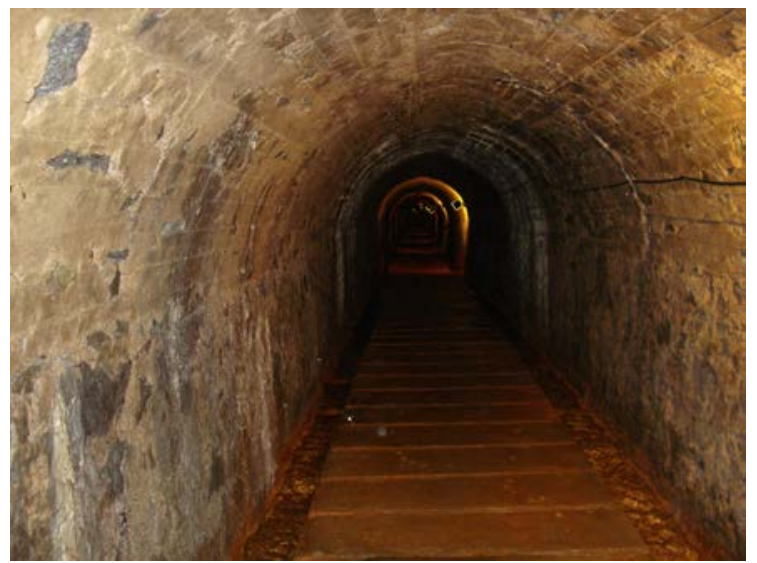

Fotografia 11. Interior de la galeria musealitzada

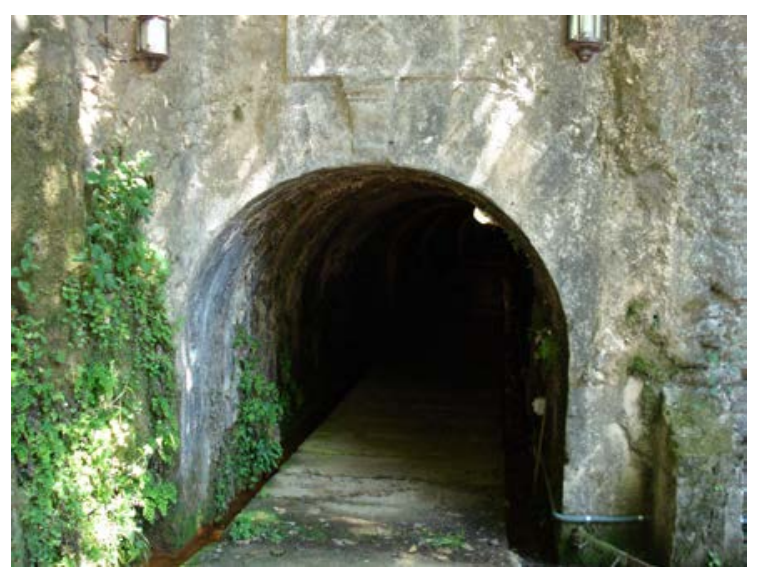

Fotografia 12. Boca mina. Mina Dolça

\subsection{Parada 11. GRAVERA D'OGASSA, CARRETERA A SANT JUAN DE LES ABADESSES, (terme municipal d'Ogassa, comarca del Ripollès). (Full 256).}

Tot seguit, després de realitzar la parada anterior, cal continuar cap e Sud, per la carretera local GiV - 5211. A uns $3 \mathrm{Km}$ de la parada anterior, en podem realitzar una altra, prop de la carretera.

En aquest recorregut, hem anat trobant afloraments dels materials del Carbonífer. Tanmateix, haurem trobat afloraments (més avall) dels trams rogencs i grisencs del Garumnià (és a dir, del nivells del trànsit entre el Cretàcic Superior i el Paleocè). Ara a l'indret de I'aturada, estem veient els nivells carbonatats cretàcics del Garumnià, de les anomenades "calcaries de Vallcebre". Així, aquests són els materials que e troben a l'indret de l'aturada.

En aquest indret hi ha una antiga explotació d'aquests materials carbonatats. (fotografies $13 \mathrm{i}$ 14). També cal dir, que al costat de l'explotació hi ha les restes d'unes antigues cimenteres, les quals formen part del nostre Patrimoni Miner.

Xaragall.2014 n.7 | Recorregut circular de recerca geològica i mineralògica per la comarca del Ripollès: des de Sant Joan de les Abadesses a les Mines de Perella, Sant Pau Seguries, Colònia Estevenell, Surroca, 


\subsection{Parada 12 - CONDICIONAL. ESTACIÓ DE L'ANTIC FERROCARRIL DE SANT JUAN DE LES ABADESSES, (terme municipal de Sant Joan de les Abadesses, comarca del Ripollès). (Full 256).}

Després de realitzar la parada anterior, cal seguir cap a Sant Joan de les Abadesses. En arribar a l’Estació d la RENFE, prop de la cruïlla de la carretera local GiV - 5211 amb la carreteres C -38. En arribar a l'Estació, farem la darrera aturada, a uns $3 \mathrm{Km}$ de l'anterior,

En aquest recorregut, efectuat sempre dintre del Mantell del Cadí, haurem trobat afloraments dels materials cenozoics de l'Eocè Inferior, els quals en bona part pertanyen a l'́lerdià.

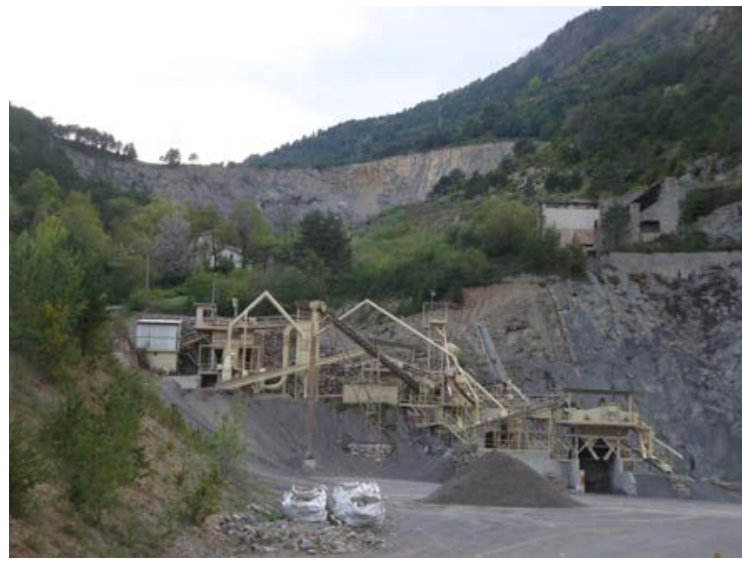

Fotografia 13. Instal-lacions de la pedrera

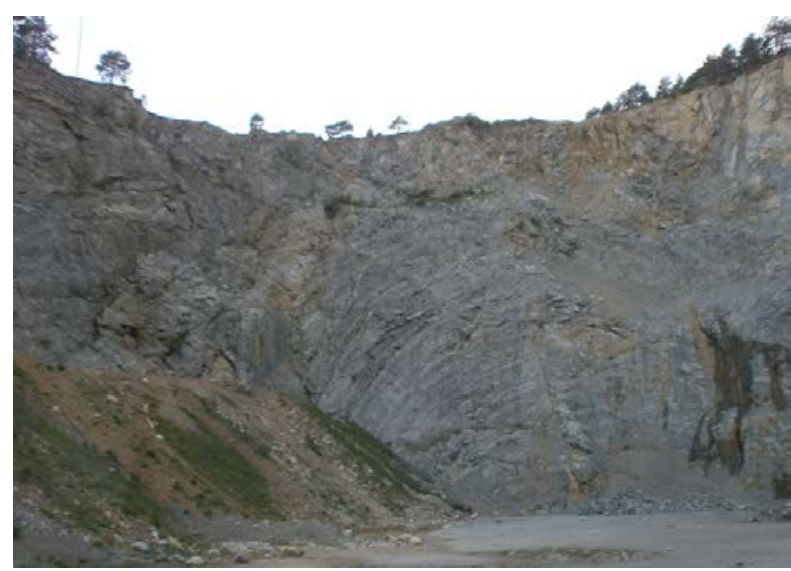

Fotografia 14. Front d'explotació de la pedrera

En aquest indret finalitza el recorregut de l'itinerari.

Xaragall.2014 n.7 | Recorregut circular de recerca geològica i mineralògica per la comarca del Ripollès: des de Sant Joan de les Abadesses a les Mines de Perella, Sant Pau Seguries, Colònia Estevenell, Surroca, 


\section{Bibliografia}

GUIMERÀ, J. et altri (1992).- GEOLOGIA (II), Història Natural dels Països Catalans, Vol. 2, 547 pag. Enciclopèdia catalana, S.A., Barcelona.

IGME (1991a).- Mapa Geológico de España a escala 1:50.000 (sintesis de la cartografia existente). Full i memòria número 255 (la Pobla de Lillet). Inst. Geol. Minero de España, Minist Indústria. Madrid.

IGME (1991b).- Mapa Geológico de España a escala 1:50.000 (sintesis de la cartografia existente). Full i memòria número 256 (Ripoll). Inst. Geol. Minero de España, Minist Indústria. Madrid.

MATA-PERELLÓ, J.M. (1991).- Els Minerals de Catalunya. Arxius de la Secció de Ciències, t. XCIII, 442 pag. Institut d’Estudis Catalans. Barcelona.

MATA-PERELLÓ, J.M. (1996).- Itinerari pel Ripollès: de Sant Pau de Seguries a Ogassa, Ribes i Pardines-l'Abella. Inèdit, 14 pàgines

MATA-PERELLÓ, J.M. (1997).- Recerca geològica i mineralògica per les comarques del Ripollès i del Vallespir: des de Surroca a Camprodon, i des de Setcases a Molló. Inèdit, 12 pag. Manresa.

MATA-PERELLÓ, J.M. (2000).- Recorregut de recerca geològica i mineralògica per la comarca del Ripollès: des de la Colònia ESTEVENELL i Camprodon a I'Abella, a Pardines i a Queralbs. Inèdit. 13 pag. Manresa

MATA-PERELLÓ, J.M. (2007).- Recerca geològica i mineralògica per la comarca del Ripollès: des de Sant Joan de les Abadesses i Surroca, a Camprodon, I'Abella i a Pardines. Inèdit. 10 pàgines. Manresa

MATA-PERELLÓ, J.M. (2011a).- Recerca geològica y mineralògica per la comarca del Ripollès: des de Sant Joan de les Abadesses i Surroca a Camprodon. Inèdit. 8 pàgines. Manresa

MATA-PERELLÓ, J.M. (2011a).- Recerca geològica i mineralògica per la comarca del Ripollès: des de Sant Joan de les Abadesses a les Mines de Perella, Surroca, a Bruguera i a Ribes de Fresser. Inèdit, 8 pàgines Manresa

MATA-PERELLÓ, J.M. i SANZ BALAGUÉ, J. (1993).- Guia de Identificación de minerales, Edit. Parcir, 244 pag. Barcelona.

RIBA ARDERIU, O. Et altri. (1976).- Geografia física dels Països Catalans. Edit Ketres. Barcelona.

Xaragall.2014 n.7 | Recorregut circular de recerca geològica i mineralògica per la comarca del Ripollès: des de Sant Joan de les Abadesses a les Mines de Perella, Sant Pau Seguries, Colònia Estevenell, Surroca, 